\title{
REFERENCES
}

1. L. A. Salei, D. P. Popa, and G. V. Lazur'evskii, KhPS [Chemistry of Natural Compounds], 2, 249, 1966. 2. R. G. Curtis, I. Heilbron, E. R. H. Jones, and G. F. Woods, J. Chem. Soc., 457, 1953.

3. The Biochemistry of Phenolic Compounds [in Russian], Moscow, p. 79, 1968.

4. Dictionary of Organic Compounds [Russian translation], Moscow, vol. III, p. 622, 1949.

10 December 1968

Institute of Chemistry, AS Moldavian SSR

UDC 547.9

\section{PHENOLIC GLYCOSIDES OF SALIX PENTANDROIDES}

\section{A. Kompantsev}

Khimiya Prirodnykh Soedinenii, VoI. 5, No. 3, p. 183, 1969

We have studied the phenolic compounds of the leaves of Salix pentandroides A. Skv. (the raw material was collected in the Teberda reserve). By two-dimensional paper chromatography with the subsequent use of qualitative reactions, we established the presence in the leaves of seven compounds of phenolic nature, of which three were obtained in the pure state. The dried leaves $(1.8 \mathrm{~kg})$ were exhaustively extracted with $70 \%$ ethanol. The ethanolic extracts were concentrated under vacuum, diluted with water, and treated with chloroform. The purified aqueous fraction was extracted with ethyl acetate. The ethyl acetate extract deposited hyperoside (quercetin 3-O-B-D-galacetopyranoside), $\mathrm{C}_{21} \mathrm{H}_{20} \mathrm{O}_{12}$, in the crystalline form with $\mathrm{mp} 232-235^{\circ} \mathrm{C}$ (from ethanol), $[\alpha]_{\mathrm{D}}^{20}-59^{\circ}$ (c 0.5 ; ethanol), $\lambda_{\max } 362,259 \mathrm{~m} \mu[1]$.

After the treatment of the aqueous fraction with ethyl acetate, extraction was continued with a mixture of ethyl acetate and ethanol $(3: 1)$. Fractional recrystallization yielded the phenol glycoside salicin (saligenin $O-\beta$ - D-glucopyranoside), $\mathrm{C}_{18} \mathrm{H}_{18} \mathrm{O}_{7}$, with $\mathrm{mp} 201-203^{\circ} \mathrm{C}$ (from ethyl acetate saturated with water), $[\alpha]_{D}^{20}-63^{\circ}$ (c 1.22; water). Melting point of the acetyl derivative, $131-134^{\circ} \mathrm{C}$ (chloroform), $[\alpha]_{D}^{20}-21^{\circ}$ (c 1.08; chloroform [2]).

After the separation of the salicin, the mother liquor was deposited on a Kapron column and was eluted first with water and then with ethanol of various concentrations. The 30\% ethanol fraction yielded quercimeritrin (quercetin 7-O$\beta$-D-glucopyranoside), $\mathrm{C}_{21} \mathrm{H}_{20} \mathrm{O}_{12}$, with $\mathrm{mp} 256-259^{\circ} \mathrm{C}$ (from acetone), $[\alpha]_{\mathrm{D}}^{20}-58^{\circ}[\mathrm{c} 0.24$; methanol-pyridine (5:1)], $\lambda_{\max } 371,258 \mathrm{~m} \mu ; \mathrm{mp}$ of the acetyl derivative $210-212^{\circ} \mathrm{C}$ (chloroform-petroleum ether) [3].

\section{REFERENCES}

1. E. T. Oganesyan, V. A. Bandyukova, and A. L. Shinkarenko, Rast. resursy, 4, 2, 240, 1968.

2. H. Thieme, Die Pharmazie, 7, 471, 1964.

3. L. Attree and A. Perkin, J. Chem. Soc., 234, 1927.

20 December 1968

Pyatigorsk Pharmaceutical Institute

UDC $661.715,668.53$

THE PRESENCE OF ALLOOCIMENE IN THE TURPENTINE FROM

PINUS SILVESTRIS

I. I. Bardyshev and E. P. Dontsova

Khimiya Prirodnykh Soedinenii, Vol. 5, No. 3, pp. 183-184, 1969

Alloocimene (2,6-dimethylocta-2,4,6-triene) has been found previously in the dry-distillation turpentine of the pine stumps that have been present in peat beds for 1000 years [1].

We have shown the presence of this hydrocarbon in commercial samples of Russian turpentines from $\underline{P \text {. silvestris }}$

L. (Scotch pine). 